\title{
Moellerella wisconsensis as a cause of peritonitis in a continuous ambulatory peritoneal dialysis patient
}

\author{
Sürekli ayaktan periton diyalizi hastasında peritonit nedeni olarak Moellerella \\ wisconsensis
}

Neslihan Yılmaz, Ahmet Çalışkan, Tülay Becerir, Selçuk Yüksel

Gönderilme tarihi:31.01.2021

Kabul tarihi:03.03.2021

\begin{abstract}
In this article, a 16-year-old girl who developed peritonitis due to Moellerella wisconsensis while being treated by continuous ambulatory peritoneal dialysis (CAPD) as renal replacement therapy is presented. Moellerella wisconsensis is a gram-negative, facultative anaerobic bacillus and a member of the Enterobacteriacea family. Its natural habitat is not well known. However, it has been isolated from patients with diarrhea, cholecystitis and bacteremia. In recent years, unexpected bacteria have been observing as the cause of peritonitis in CAPD patients, and this is the first case of peritonitis due to Moellerella wisconsensis in a child with CAPD in the English medical literature.
\end{abstract}

Key words: Peritonitis, children, peritoneal dialysis, enterobacteriaceae.

Yilmaz N, Caliskan A, Becerir T, Yuksel S. Moellerella wisconsensis as a cause of peritonitis in a continuous ambulatory peritoneal dialysis patient. Pam Med J 2022;15:187-189.

Öz

Bu yazıda, böbrek replasman tedavisi olarak sürekli ayaktan periton diyalizi (SAPD) ile tedavi edilirken Moellerella wisconsensis'e bağlı peritonit gelişen 16 yaşında bir kız çocuğu sunulmuştur. Moellerella wisconsensis, gram negatif, fakültatif anaerobik bir basildir ve Enterobacteriacea ailesinin bir üyesidir. Doğal yaşam alanı çok iyi bilinmemektedir. Ancak ishal, kolesistit ve bakteriyemili hastalardan izole edilmiştir. Son yıllarda SAPD hastalarında peritonit nedeni olarak beklenmedik bakteriler gözlemlenmektedir ve bu, İngiliz tıp literatüründe CAPD'li bir çocukta Moellerella wisconsensis'e bağlı ilk peritonit olgusudur.

Anahtar kelimeler: Peritonit, çocuklar, periton diyalizi, enterobacteriaceae.

Yılmaz N, Çalışkan A, Becerir T, Yüksel S. Sürekli ayaktan periton diyalizi hastasında peritonit nedeni olarak Moellerella wisconsensis. Pam Tıp Derg 2022;15:187-189.

\section{Introduction}

Bacterial peritonitis is one of the major complications in patients undergoing peritoneal dialysis. Notably, unexpected bacteria have observed as peritonitis agents among such patients in recent years. We present a case of a girl with continuous ambulatory peritoneal dialysis (CAPD) who developed peritonitis due to Moellerella wisconsensis.

\section{Case report}

A 16-year-old girl with CAPD who had been followed up in another pediatric nephrology division for 5 years was admitted to our pediatric nephrology department for the first time with complaints of abdominal pain and cloudy dialysate. Her medical history revealed that 6 years prior, she had undergone kidney transplantation with her mother as a donor at the same center, but rejection developed 1 year after the transplant due to non-compliance with the immunosuppressive medication. Her medical epicrisis revealed that she suffered from 5 peritonitis attacks due to Acinetobacter Iwoffii, Enterobacter cloacae, and Klebsiella oxytoca (two times, two times, and one time, respectively). A catheter had been re-implanted due to a technical failure during this period.

Neslihan Yılmaz, M. D. Pamukkale University School of Medicine, Department of Pediatric Nephrology, Denizli, Turkey, e-mail: nefrolojineslihan@ gmail.com (https://orcid.org/0000-0001-8518-538X) (Corresponding Author)

Ahmet Çalışkan, M. D. Pamukkale University School of Medicine, Department of Microbiology, Denizli, Turkey, e-mail: acaliskan@pau.edu.tr (https:// orcid.org/0000-0002-1156-3787)

Tülay Becerir, M. D. Pamukkale University School of Medicine, Department of Pediatric Nephrology, Denizli, Turkey, e-mail: tlyince@hotmail.com (https://orcid.org/0000-0001-6277-1458)

Selçuk Yüksel, Prof. Dr. Pamukkale University School of Medicine, Department of Pediatric Rheumatology and Pediatric Nephrology, Denizli, Turkey, e-mail: selcukyuksel.nephrology@gmail.com (https://orcid.org/0000-0001-9415-1640) 
Physical examination revealed normal body temperature $\left(36^{\circ} \mathrm{C}\right)$, abdominal tenderness, and a normal catheter exit site. Microscopic examination showed increased leukocyte count in the dialysate $\left(6459 / \mathrm{mm}^{3}, 90 \%\right.$ neutrophil dominance), but no microorganisms were observed in Gram staining. Cefepime (500 $\mathrm{mg} / \mathrm{L}$ loading and $125 \mathrm{mg} / \mathrm{L}$ maintenance) was started empirically. Leukocytes disappeared in the peritoneal fluid, and the symptoms improved within 3 days after treatment. M. wisconsensis was isolated from the patient's peritoneal fluid (Table 1), but the antibiotic regimen was not changed because of clinical and laboratory improvement. On the 14th day, the patient had completely normal clinical and laboratory findings. The catheter was not removed. During the 1-year follow-up of the patient, there was no peritonitis attack.

\section{Discussion}

According to the English medical literature (PubMed/MEDLINE, Google Scholar, Scopus), this is the first report of a case of peritonitis due to $M$. wisconsensis in a child with CAPD. In Turkish medical literature, however, there is a case report of peritonitis due to $M$. wisconsensis associated with peritoneal dialysis in a 33-yearold adult with CAPD. Intravenous meropenem and intraperitoneal 8" gentamicin were given to that patient, who recovered without the need for catheter replacement [1]. Intraperitoneal antibiotic treatment was administered for 14 days in this case. Similarly, we treated our patient with intraperitoneal antibiotics for 2 weeks, which is the recommended duration of treatment for single Gram-negative organisms except for Pseudomonas/Stenotrophomonas species, for which therapy should be 3 weeks [2].

Table 1. In vitro susceptibility profile of Moellerella wisconsensis isolate

\begin{tabular}{lll}
\hline Antibiotic & Susceptibility & MIC Values (mg/L) \\
\hline Amikacin & Susceptible & $\leq 8$ \\
Amoxicillin clavulanate & Susceptible & $\leq 1$ \\
Ampicillin/sulbactam & Susceptible & $\leq 0.125$ \\
Ampicillin & Resistant & $>16$ \\
Ceftazidime & Susceptible & $\leq 2$ \\
Gentamicin & Susceptible & $\leq 2$ \\
Ceftriaxone & Susceptible & $\leq 1$ \\
Imipenem & Susceptible & $\leq 0.25$ \\
Meropenem & Susceptible & $\leq 0.125$ \\
Piperacillin/tazobactam & Susceptible & $\leq 1$ \\
Trimethoprim/sulfamethoxazole & Susceptible & $\leq 0.052$ \\
\hline
\end{tabular}

M. wisconsensis is a Gram-negative, facultative, anaerobic bacillus in the family Enterobacteriacea. Although its pathogenicity is not fully known, it has attracted attention since Hickman Brenner et al. [3] isolated it for the first time from the stool of a patient with diarrhea. Its natural habitat is not well known, but it has been isolated from un-chlorinated water and food. Generally, M. wisconsensis has been isolated from patients with diarrhea, cholecystitis, and bacteremia [4].

M. wisconsensis has the general characteristics of the Enterobacteriaceae family, but some of its biochemical properties and antibiotic sensitivities distinguish it from other Enterobacteriaceae species. M. wisconsensis colonies can be distinguished from $E$. coli by a positive citrate-test result, as well as negative and immobile results in indole and lysine decarboxylase tests. However, complete identification cannot be achieved in routine practice. API 20E (BioMe'rieux, Marcyl Etoile, France) and Micronaut-E (Merlin-Diagnostika, Bornheim, Germany) are frequently used automated identification systems that can accurately identify the bacteria at the species level [5].

In our microbiology laboratory, the patient's peritoneal fluid was inoculated in agar medium with $5 \%$ sheep blood, eosin methylene blue medium, and chocolate medium. After 18-24 hours of incubation at $37^{\circ} \mathrm{C}$, the tests performed 
comprised microorganism colony morphology, staining characteristics, oxidase and catalase, Gram-negative identification, citrate, indole, urea, triple sugar iron agar, and motility tests. The exact identification of the bacteria was achieved with a Phoenix 100 (Becton Dickinson, Maryland, USA) automated culture and antibiotic susceptibility system [6]. Antibiotic sensitivities were evaluated according to the EUCAS T recommendations with the same automated system (Table 1).

M. wisconsensis is sensitive to many antibiotics that are effective against Gramnegative bacteria. It is sensitive to doxycycline, aminoglycosides, oxacillin, $\beta$-lactam antibiotics, fluoroquinolones, chloramphenicol, and nitrofurantoin, but rarely, it is resistant to tetracycline and trimethoprim/sulfamethoxazole [5]. In our case, it was found to be sensitive to all antibiotics except ampicillin (Table 1).

This microorganism is mostly isolated from the gastrointestinal system as a cause of disease in humans, and its virulence is not exactly known. A low prevalence of $0.75 \%$ is reported in the stools of adults with diarrhea [7]. However, it is appropriate to consider that in easily contaminated patients such as those with peritoneal dialysis, it can be easily treated, even if catheter removal is not required.

The patient is a textile worker and lives in a family of 8 people. She does not have a room of her own. There was no hemodialysis center close to the patient's residence. She had chosen CAPD as renal replacement therapy and has been performing CAPD on her own. She has not been denying that she has problems in terms of compliance with hygiene rules while applying CAPD. Therefore, we concluded that her peritoneal fluid might have been contaminated as a result of not paying attention to hand hygiene. Patients and families should be given detailed information about the sources and transmission routes of this type of microorganism, which is rarely seen as a cause of peritonitis.

Conflict of interest: The authors declare no conflict of interest.

\section{References}

1. Çerçioğlu D, Karaköse S, Bal AZ, Kaya Kılıç E. Moellerella wisconsensis'e bağlı olarak gelişen periton diyalizi ile ilişkili peritonit olgusu. Ortadogu Tıp Derg 2019;1:85-87. https://doi.org/10.21601/ ortadogutipdergisi.363862

2. Chadha V, Schaefer F, Warady BA. Peritonitis and exitsite infections. In: Warady BA, Schaefer FS, Alexander SR. (eds.) Pediatric Dialysis. Springer, Boston, MA. https://doi.org/10.1007/978-1-4614-0721-8_14

3. Hickman Brenner FW, Huntley Carter GP, Saitoh Y, Steigerwalt AG, Farmer JJ III, Brenner DJ. Moellerella wisconsensis, a new Genus and species of Enterobacteriaceae found in human stool specimens. J Clin Microbiol 1984;19:460-463. https://doi. org/10.1128/JCM.19.4.460-463.1984

4. Cardentey Reyes A, Jacobs F, Struelens MJ, Rodriguez Villalobos H. First case of bacteremia caused by Moellerella wisconsensis: case report and a review of the literature. Infection 2009;37:544-546. https://doi. org/10.1007/s15010-009-8446-3

5. Stock I, Falsen E, Wiedemann B. Moellerella wisconsensis: identification, natural antibiotic susceptibility and its dependency on the medium applied. Diagn Microbiol Infect Dis 2003;45:1-11. https://doi.org/10.1016/s0732-8893(02)00483-2

6. Laboratory procedure. Available at: https://legacy. bd.com/ds/technicalCenter/clsi/clsi-Phoenix_ GramNegative_V5.15_V4.31.pdf. Accessed August 31,2020

7. Marshall AR, Al Jumaili IJ, Bint AJ. The isolation of Moellerella wisconsensis from stool samples in the UK. J Infect 1986;12:31-33. https://doi.org/10.1016/s01634453(86)94804-8

Informed consent: Written informed consent was obtained from the patient.

\section{Contributions of the authors to the article}

N.Y., A.Ç, T.B. and S.Y. contributed to the design and implementation of the research, to the analysis of the results and to the writing of the manuscript. In addition, all authors discussed the entire study and approved its final version. 